\title{
Distribution and Source Determination of Rare Earth Elements in Sediment Collected From The Continental Shelf Off Hainan Island, China
}

\section{Pengjie Cai ( $\sim$ caipengjie@cug.edu.cn )}

Guangzhou Marine Geological Survey https://orcid.org/0000-0002-4082-4499

\section{Guanqiang Cai}

Guangzhou Marine Geological Survey

\section{Xuejie Li}

Guangzhou Marine Geological Survey

\section{Xin Chen}

China University of Geosciences

Jie Lin

Guangzhou Marine Geological Survey

Shun Li

Guangzhou Marine Geological Survey

\section{Zhao Li}

Guangzhou Marine Geological Survey

\section{Research Article}

Keywords: REE, Distribution, Enrichment factor, Sediment source, Continental shelf off Hainan Island, China

Posted Date: June 22nd, 2021

DOI: https://doi.org/10.21203/rs.3.rs-575805/v1

License: (c) (i) This work is licensed under a Creative Commons Attribution 4.0 International License. Read Full License

Version of Record: A version of this preprint was published at Environmental Science and Pollution Research on August 12th, 2021. See the published version at https://doi.org/10.1007/s11356-021-15818$\mathrm{x}$. 


\section{Abstract}

Contents of rare earth elements (REEs), major elements and the Total Organic Carbon (TOC) were determined for 152 surface sediment samples collected from the continental shelf off Hainan Island $(\mathrm{CSHI})$. From high to low, the average contents of REEs were: $\mathrm{Ce}>\mathrm{La}>\mathrm{Nd}>\mathrm{Pr}>\mathrm{Sm}>\mathrm{Gd}>\mathrm{Dy}>\mathrm{Er}>\mathrm{Yb}>$ $\mathrm{Eu}>\mathrm{Ho}>\mathrm{Tb}>\mathrm{Tm}>\mathrm{Tm}$. The concentrations of REEs in the north of the study area were higher than in the south. The LREE concentrations in the south were higher than in the north. This resulted higher values for the LREE/HREE ratio in the south than in the north. The mean EF could be arranged from highest to lowest as follows: $\mathrm{Tm}>\mathrm{Sm}>\mathrm{Pr}>\mathrm{Er}>\mathrm{La}>\mathrm{Lu}>\mathrm{Ce}>\mathrm{Tb}>\mathrm{Eu}>\mathrm{Nd}>\mathrm{Yb}>\mathrm{Gd}>\mathrm{Ho}>\mathrm{Dy}$. The enrichment factor $(E F)$ indicates that pollution as a result of human activity was more serious in the southeast of the study area than in the north. The factors affecting the REE concentrations in this area include naturally occurring minerals and industrial pollution. Based on the spatial variation of upper continental crust (UCC)-normalized REE concentrations, the CSHI was classified into three geochemical provinces. The sediment of province I was controlled by the Red and Pearl rivers. The composition of the province II is mainly controlled by the Red River and the Pearl River, although some sediments have originated from the South China Sea Island. Province III sediments mainly originated from sources on Hainan Island.

\section{Introduction}

Rare earth elements (REEs), a group of related lanthanides (McLennan, 1980); have been used as indicators of geochemical processes. Examples of these geochemical processes include the chemical evolution of the crust and mantle (Cai et al., 2021a), tectonic evolution (Chen et al., 2020), surficial weathering (Hannigan et al., 2010; Qiao et al., 2020) and for identifying the source of material in different environmental systems (Delgado et al., 2012; Khan et al., 2016; da Silva et al., 2018; Li et al., 2018; Oral et al., 2019). In studies of marine sediments, REEs have been used as important indicators for sediment source tracking (Wang et al., 2014), climate change (Hatano et al., 2020), and environmental assessment (González et al., 2014; Herrmann et al., 2016; Renjan et al., 2017; Trifuoggi et al., 2018). REEs are not used as indicators of environmental pollution as often as heavy metals (e.g., $\mathrm{Cu}, \mathrm{Pb}, \mathrm{Zn}, \mathrm{Cr}, \mathrm{Co}, \mathrm{Ni}, \mathrm{Cd}$, and $\mathrm{Hg}$ ). However, REEs are widely used in industry, which will change their content in sediments (Trifuoggi et al., 2018). The distribution, transport, and generation of REEs in continental shelf surface sediments have started to attract the attention of researchers (Wu et al., 2020).

Hainan Island is located in the northwestern reaches of the South China Sea (SCS). It is the second largest island in China, with an area of more than 30000 square kilometers (Fig. 1a). The concentrations of contaminants in the surface sediments off the Island used to be relatively low, but in recent years, the rapid development of industry, agriculture, domestic sewage discharge, and tourism have been associated with a decrease in environmental quality (Mo et al., 2019; Cai et al., 2021b). Most previous studies of the chemical composition of the marine sediments have had a heavy metal focus and only considered part of the continental shelf off Hainan Island (CSHI)(Hu et al., 2013; Xu et al., 2015; Zhao et al., 2020; Cai et al., 2021b). No studies have considered the concentration and distribution of REEs in the sediments off the island. This has limited the assessment of environmental change in this area. 
In this study, the concentrations of REEs, major elements and TOC in surface sediments collected from the CSHI were determined. As the distribution of REEs in the surface sediments has never been reported before, the data can be used as a baseline for future research. The aims of this paper were: (i) to identify the distribution of REEs in surface sediments collected from the CSHI; (ii) to calculate the enrichment factor (EF) value of REEs and its spatial variation; (iii) to determine whether the enrichment of REE is related to human activities; (iv) to identify the potential sources of REEs in surface sediments collected from the CSHI. The purpose of this study is to provide a scientific basis for environmental management of the CSHI, with particular reference to the distribution of REEs in marine sediments. In addition, we hope that the results presented in this study can contribute to an understanding of the distribution, sources and associated risks of REEs in continental shelf environments in other parts of the world.

\section{Materials And Methods \\ 2.1 Regional setting}

The study area is located in the southwestern part of continental shelf of the northern reaches of the SCS (Fig. 1b). The western part of the study area is the Beibu Gulf, the eastern part is the shelf of the northern SCS, while the southern part is the western slope (Cao et al., 2019; Xu et al., 2015). The isobaths offshore are aligned parallel to the coastline. The water depth ranges from $20 \mathrm{~m}$ to $200 \mathrm{~m}$. The water depth in the western part of the study area changes gradually, while that in the East drops sharply (Huang et al., 2013). Previous studies of the chemical composition of surface sediments in this area were restricted to heavy metals (Hu et al., 2013; Xu et al., 2015; Zhao et al., 2020; Cai et al., 2021b). As their conclusions were limited to the spatial variation of heavy metal elements, their data cannot be used to provide a comprehensive baseline of environmental conditions for the CSHI.

\subsection{Analytical methods}

In this study, a grab was used to obtain 152 marine sediment samples from the CSHI in August 2019 (Fig. 1c). The work was carried out by the China Geological Survey (Project No. DD20190627). The pretreatment of samples was described by Cai et al. (2021b). The determination of REE concentrations was carried out by inductively coupled plasma-mass spectrometry (ICP-MS) at the Guangzhou Marine Geological Survey. The determination of major element $\left(\mathrm{SiO}_{2}, \mathrm{TiO}_{2}, \mathrm{Al}_{2} \mathrm{O}_{3}, \mathrm{Fe}_{2} \mathrm{O}_{3}, \mathrm{MnO}, \mathrm{MgO}, \mathrm{CaO}, \mathrm{Na}_{2} \mathrm{O}\right.$, $\mathrm{K}_{2} \mathrm{O}$, and $\mathrm{P}_{2} \mathrm{O}_{5}$ ) concentrations was carried out by X-ray Fluorescence Spectrometer (XRF). The methods used for quality control and assurance have been described in Wang et al. (2015). An element analyzer (Vario EL-III) was used to determine the Total Organic Carbon (TOC). A total of 30 parallel samples were tested, one of which was randomly selected from every five samples. The measurement error of repeated sediment analysis was within $5 \%$. This work was carried out the Geological and Environmental Institute of China, University of Geosciences, Wuhan. The statistical analyses were carried out by using IBM SPSS statistics Software (version 25). ArcMap 10.2 was used to produce maps, while Origin 2021 was used to produce the graphs. 


\section{Results And Discussion}

\subsection{Descriptive statistics for the concentrations of major elements and REEs}

The descriptive statistics for the concentrations of major elements and REEs in sediments collected from the $\mathrm{CSHI}$ have been presented in Supplementary Table 1. The average concentrations (as a percentage) of $\mathrm{SiO}_{2}, \mathrm{Al}_{2} \mathrm{O}_{3}, \mathrm{Fe}_{2} \mathrm{O}_{3}, \mathrm{CaO}, \mathrm{MgO}, \mathrm{K}_{2} \mathrm{O}, \mathrm{Na}_{2} \mathrm{O}, \mathrm{MnO}, \mathrm{P}_{2} \mathrm{O}_{5}$, and $\mathrm{TiO}_{2}$ were $60.48 \%, 11.80 \%, 4.68 \%, 5.51 \%$, $2.02 \%, 2.16 \%, 1.62 \%, 0.06 \%, 0.10 \%$, and $0.62 \%$, respectively. In addition, the average concentration of TOC was $0.58 \%$. The average concentrations (as $\mu \mathrm{g} / \mathrm{g}$ ) of $\mathrm{La}, \mathrm{Ce}, \mathrm{Pr}, \mathrm{Nd}, \mathrm{Sm}, \mathrm{Eu}, \mathrm{Gd}, \mathrm{Tb}, \mathrm{Dy}, \mathrm{Ho}, \mathrm{Er}, \mathrm{Tm}, \mathrm{Yb}$, and Lu were $35.82 \mu \mathrm{g} / \mathrm{g}, 70.83 \mu \mathrm{g} / \mathrm{g}, 8.25 \mu \mathrm{g} / \mathrm{g}, 28.85 \mu \mathrm{g} / \mathrm{g}, 5.79 \mu \mathrm{g} / \mathrm{g}, 1.09 \mu \mathrm{g} / \mathrm{g}, 4.12 \mu \mathrm{g} / \mathrm{g}, 0.78 \mu \mathrm{g} / \mathrm{g}, 3.66$ $\mu \mathrm{g} / \mathrm{g}, 0.79 \mu \mathrm{g} / \mathrm{g}, 2.65 \mu \mathrm{g} / \mathrm{g}, 0.40 \mu \mathrm{g} / \mathrm{g}, 2.19 \mu \mathrm{g} / \mathrm{g}$, and $0.36 \mu \mathrm{g} / \mathrm{g}$, respectively. The total concentration of REEs ( $($ REE) was between $44.21 \mu \mathrm{g} / \mathrm{g}$ and $221.68 \mu \mathrm{g} / \mathrm{g}$ (mean of $165.57 \mu \mathrm{g} / \mathrm{g}$ ). The concentration of light REEs (LREEs, mean of $150.62 \mu \mathrm{g} / \mathrm{g}$ ) was higher than for the heavy REEs (HREE, mean of 14.95 $\mu \mathrm{g} / \mathrm{g}$ ) in the sediment samples. Wilding (1985) divided coefficient of variation (CV) into three degrees of variation, namely low variation $(\mathrm{CV}<0.16)$, moderate variation $(0.16<\mathrm{CV}<0.36)$, and high variation $(\mathrm{CV}>$ 0.36). The variation coefficients of $\mathrm{La}, \mathrm{Ce}, \mathrm{Pr}, \mathrm{Nd}, \mathrm{Sm}, \mathrm{Eu}, \mathrm{Tb}, \mathrm{Dy}, \mathrm{Ho}, \mathrm{Er}, \mathrm{Tm}, \mathrm{Yb}$, and Lu displayed a moderate degree of variation, namely $0.22,0.22,0.22,0.24,0.20,0.24,0.33,0.33,0.29,0.32,0.31$, respectively (Supplementary Table 1). The result showed that $\mathrm{Gd}$ had a high degree of variation, with a variation coefficient of 0.44 . In conclusion, all the REEs of the CSHI show moderate to high variability, indicating that they may be affected by human activities.

\subsection{The distribution of REEs across the CSHI}

REE concentrations in surface sediment samples of the CSHI are shown in Supplementary Table 1 and Fig. 2. Concentrations of the REEs in samples ranged from $44.21 \mu \mathrm{g} / \mathrm{g}$ to $221.68 \mu \mathrm{g} / \mathrm{g}$. In the measured REEs, the content of $\mathrm{Ce}(16.00 \sim 94.21$, mean 70.83) was the highest, while the contents of $\operatorname{Tm}(0.1 \sim$ 0.73 , mean 0.40$)$ and Lu (0.08 0.65, mean 0.36) were the lowest. All samples showed that LREE (La, Ce, $\mathrm{Pr}, \mathrm{Nd}, \mathrm{Sm}$, and Eu) were more enriched than HREE (Gd, Tb, Dy, Ho, Er, Tm, Yb, and Lu). The LREE/HREE ratio ranged from 7.81 to 16.87 . The distributions of REEs are shown in the Fig. 3 . The concentrations of REEs in the north of study area were higher than in the south. The LREEs in the south are more abundant than in the north, which is shown by the higher LREE/HREE values in south than in the north.

\subsection{Comparison of REE concentrations from the CSHI with the results from other areas}

The mean concentrations of REEs in marine sediments collected from other continental shelves have been presented in Supplementary Table 2. The mean concentration of REEs observed in the CSHI were significantly higher than those reported for the Rea Sea (El-Tahera et al., 2019), Western Gulf of Thailand (Liu et al., 2019), Western Sunda Shelf (Wu et al., 2020), Chukchi Sea (Astakhov et al., 2019), and Eastern Gulf of Tigullio (Consani et al., 2020). However, the mean concentrations of REEs in the CSHI were similar to those reported for the East Siberian Sea (Astakhov et al., 2019). Compared with other areas in China, 
the mean concentrations of REEs in the sediments collected from the CSHI were similar to those reported for the Yellow Sea (Mi et al., 2020), Bohai Bay (Zhang and Gao et al., 2015), and East China Sea (Mi et al., 2020). It is worth noting that the continental shelf of China has a higher background value of REEs, and is more likely to reach the critical value of pollution because of human activities.

\subsection{Enrichment factor (EF) of REEs}

The enrichment factor (EF) of REEs in surface sediments can be used to evaluate the degree of anthropogenic pollution (N'Guessan et al., 2009). Al, Fe, and Ti are often used as reference elements due to their chemical stability (N'Guessan et al., 2009). In this study, the concentration of Ti vs. REEs showed a low coefficient of variation (0.27) and a high correlation (0.73), so Ti was used as a reference value to calculate the EF. The EF values of REEs in sediments were calculated by using formula (1).

$\mathrm{EF}=(\mathrm{Ci} / \mathrm{Ti})_{\text {sample }} /(\mathrm{Ci} / \mathrm{Ti})_{\text {background }}(1)$

$(\mathrm{Ci} / \mathrm{Ti})_{\text {sample }}$ was the ratio of REEs and Ti concentrations in the sample, while $(\mathrm{Ci} / \mathrm{Ti})_{\text {background }}$ was the ratio of REEs and Ti concentrations in the upper continental crust. Sutherland (2000) assigned levels of pollution to one of five classes according to the EF value as follows: (i) $E F<2$ (no or minimal pollution); (ii) $2 \leq \mathrm{EF}<5$ (moderate level of pollution); (iii) $5 \leq \mathrm{EF}<20$ (significant level of pollution); (iv) $20 \leq \mathrm{EF}<40$ (very high level of pollution); $v$ ) $\mathrm{EF}>40$ (extremely high level of pollution).

The calculated EF values for REEs for this study have been presented in Supplementary Table 3. The ranges (mean in parentheses) of the EF of La, Ce, Pr, Nd, Sm, Eu, Gd, Tb, Dy, Ho, Er, Tm, Yb, and Lu in the study area were $0.76-4.58(1.24), 0.74-3.36(1.21), 0.73-7.80(1.27), 0.68-6.26(1.16), 0.73-4.17$ (1.33), $0.60-3.75$ (1.16), 0.22-3.58 (1.06), 0.22-3.32 (1.19), 0.66-2.59 (0.98), 0.5-2.01 (1.00), 0.59-2.43 (1.24), $0.75-2.53$ (1.41), 0.77-3.20 (1.15), and 0.67-4.69 (1.23), respectively. The mean EF values could arranged from highest to lowest as follows, $\mathrm{Tm}>\mathrm{Sm}>\mathrm{Pr}>\mathrm{Er}>\mathrm{La}>\mathrm{Lu}>\mathrm{Ce}>\mathrm{Tb}>\mathrm{Eu}>\mathrm{Nd}>\mathrm{Yb}>\mathrm{Gd}>\mathrm{Ho}>$ Dy. The mean EF values of REEs in surface sediments ranged from 0.98 to 1.41 (Fig. 4), which indicates all samples could be assigned to the no or minimal pollution class (Sutherland, 2000). However, the maximum values for individual elements indicate different levels of pollution. The maximum EF values of Pr and Nd were 7.80 and 6.26 respectively, consistent with the significant pollution class described above. The maximum EF values of the other rare earth elements are between 2 to 5 , which would indicate moderate levels of pollution. The distribution of EF for REEs in the CSHI have been showed in the Fig. 5 . There is no pollution by REEs in the northern reaches of the CSHI. However, the EF values of REEs in the southeast of the shelf near Hainan Island are the highest, which could be attributed to human activity. This may be related to the close proximity of this area to Wenchang City, a city with a range of industries and port facility.

\subsection{The correlation analysis between major elements and REEs in the sediment}

The correlations between major elements and REEs are shown in Fig. 6. The depth of color in the graph is based on the strength of the correlational relationship between the variables. REEs are correlated with 
$\mathrm{TiO}_{2}$ (always $\geq 0.66$ ), indicating that REEs are hosted in rutile. There is no correlation between TOC and REEs, indicating that the content of organic matter has no effect on the distribution of REEs in sediments. It is well known that acidic mine drainage can form small-scale (colloidal) "iron hydroxide" deposits (Ayora et al., 2016). These hydroxides can enrich REEs by precipitation and adsorption (Barcelos et al., 2018), and then enter the sediments through the so-called "salting out" process (Sholkovitz and Szymczak, 2000; Kulaksiz and Bau, 2007). This also explains the high correlation between $\mathrm{Fe}_{2} \mathrm{O}_{3}$ and REEs (always $\geq 0.44$ ). There is also a high correlation between $\mathrm{Al}_{2} \mathrm{O}_{3}$ and REEs (always $\geq 0.41$ ), while REEs may also occur in clay minerals. There is a significant correlation among the REEs, which indicates that the factors controlling the spatial variation in the concentrations in the sediments should be the same (Wang et al., 2019). In general, the main factors affecting the distribution of REEs in this area are the composition of naturally occurring minerals and industrial pollution.

\subsection{Sediment source discrimination}

The upper continental crust (UCC)-normalized REE concentrations are often used to identify the source of sediments (Hossain et al., 2010; Wu et al., 2020). The results of UCC-normalized REE concentrations are showed in Fig. 7. The sediments of the CSHI can be divided into three provinces.

Province I is the northeastern area of the CSHI near the mouth of the Pearl River. The Pearl River, the largest river in southern China, discharges $84.30 \mathrm{Mt}$ of suspended particulate matter into the SCS each year (Cao et al., 2019). The UCC-normalized REE patterns for sediments from province I are similar to those for the Pearl River and Red River (Fig. 7a). This indicates that the northern part of the region is affected by the Pearl River, while the Red River sediments enter the region through the Qiongzhou Strait. This would also explain the high REEs concentrations in the north and the Qiongzhou Strait (Fig. 3). Province II is in the northwestern part of the Hainan Island shelf, with the Red River in the north. The spatial variation in UCC-normalized REE concentrations for province II are similar to those for the Red River and the Pearl River, but also slightly affected by sediments from Hainan Island (Fig. 7b). It also explains the higher REE concentrations in this area, which is located close to the mouth of the Red River, Qiongzhou Strait and Hainan Island (Fig. 3). The spatial variations of UCC-normalized REE concentrations in province III are different from the other two provinces, which indicates the importance of Hainan Island as a sediment source for province III (Fig. 7c). This is consistent with the distribution of REE from high to low in the south of CHSI (Fig. 3). In summary, the spatial variation of REEs in province I was determined by close proximity to the mouths of the Red and Pearl rivers, whereas the concentrations in sediments in province II and III could be attributed to a mixed contribution from three sources (Fig. 7d).

\section{Conclusions}

(1) The average concentrations of $\mathrm{La}, \mathrm{Ce}, \mathrm{Pr}, \mathrm{Nd}, \mathrm{Sm}, \mathrm{Eu}, \mathrm{Gd}, \mathrm{Tb}, \mathrm{Dy}, \mathrm{Ho}, \mathrm{Er}, \mathrm{Tm}, \mathrm{Yb}$, and Lu were 35.82 $\mu \mathrm{g} / \mathrm{g}, 70.83 \mu \mathrm{g} / \mathrm{g}, 8.25 \mu \mathrm{g} / \mathrm{g}, 28.85 \mu \mathrm{g} / \mathrm{g}, 5.79 \mu \mathrm{g} / \mathrm{g}, 1.09 \mu \mathrm{g} / \mathrm{g}, 4.12 \mu \mathrm{g} / \mathrm{g}, 0.78 \mu \mathrm{g} / \mathrm{g}, 3.66 \mu \mathrm{g} / \mathrm{g}, 0.79 \mu \mathrm{g} / \mathrm{g}$, $2.65 \mu \mathrm{g} / \mathrm{g}, 0.40 \mu \mathrm{g} / \mathrm{g}, 2.19 \mu \mathrm{g} / \mathrm{g}$, and $0.36 \mu \mathrm{g} / \mathrm{g}$, respectively. The $\Sigma$ REE ranges from $44.21 \mu \mathrm{g} / \mathrm{g}$ to 221.68 $\mu \mathrm{g} / \mathrm{g}$. 
(2) The EF value of REEs is the highest southeast of Hainan Island, which indicates that elevated levels of REEs in this area were affected by human activities.

(3) Based on the spatial variation of the UCC-normalized REE concentrations, the CSHI was classified into three geochemical provinces. The sediment of province I is controlled by close proximity to the mouths of the Red and Pearl rivers, while the origin of sediment in province II and III could be attributed to three sources and hence is of a more mixed composition.

\section{Declarations}

\section{Acknowledgments}

We would like to thank the editor for their constructive reviews of this paper's early version.

\section{Author contribution}

Pengjie Cai: Writing - original draft, Writing - review; \& editing. Guanqiang Cai: Writing - review \& editing, Project administration. Xuejie Li: Writing - review; Xin Chen: Software. Jie Lin: Drawing. Shun Li: Data curation. Li Zhao: Methodology, Investigation.

\section{Funding}

Funding for this research was provided by the Geological Survey Project of China Geological Survey (DD20190627, DD20160140, GZH 201400210) and National Natural Science Foundation of China (U20A20100).

\section{Availability of data and materials}

All data and materials are true and valid and can use general repositories saving.

\section{Ethical Approval}

I would like to declare on behalf of my co-authors that the work described was original research that has not been published previously, in whole or in part.

\section{Consent to participate}

All the authors listed consent to participate.

\section{Consent for publication}

All the authors listed have approved the manuscript that is enclosed.

\section{Competing interests}

The authors declare no competing interests. 


\section{References}

1. Astakhov AS, Sattarova VV, Xuefa S, Limin H, Mariash AA (2019) Distribution and sources of rare earth elements in sediments of the chukchi and east siberian seas. Polar Sci 20:148-159

2. Ayora C, Macías F, Torres E, Lozano A, Carrero S, Nieto JM, Pérez-López R,Fernández-Martínez A, Castillo-Michael H (2016) Recovery of rare earth elements and yttrium from passive-remediation systems of acid mine drainage. Environ Sci Technol 50 (15): 8255-8262

3. Barcelos GS, Welmer Veloso R, de Mello JW, V, Gasparon M (2018) Immobilization of Eu and Ho from synthetic acid mine drainage by precipitation with $\mathrm{Fe}$ and $\mathrm{Al}$ (hydr)oxides. Environ Sci Pollut Res 25:18813-18822

4. Cao L, Liu J, Shi X, He W, Chen Z (2019) Source-to-sink processes of fluvial sediments in the northern south china sea: constraints from river sediments in the coastal region of south china. J Asian Earth Sci 185:104020

5. Cai PJ, Chen X, Majka J, Klonowska I, Jeanneret P, Xu RK, Zheng YY (2021a) Two episodes of crustmantle interaction in the chromitite-bearing Luofengpo mafic-ultramafic complex produced by oceanic subduction to continental collision during the North Qaidam orogeny. Gondwana Res 89:247-264

6. Cai PJ, Cai GQ, Chen X, Li S, Zhao L (2021b) The concentration distribution and biohazard assessment of heavy metal elements in surface sediments from the continental shelf of Hainan Island. Marine Pollution Bulletin. https://doi.org/10.1016/j.marpolbul.2021.112254

7. Chen X, Zheng Y, Xu R, Gu P, Yu J, Bai J, Cai J, Jiang X (2020) Subduction channel fluid-rock interaction: Indications from rutile-quartz veins within eclogite from the Yuka terrane, North Qaidam orogen. Geosci Front 11(2):635-650

8. Consani S, Cutroneo L, Carbone C, Capello M (2020) Baseline of distribution and origin of rare earth elements in marine sediment of the coastal area of the eastern gulf of tigullio (ligurian sea, northwest italy). Mar Pollut Bull 155:111145

9. Clift PD, Long HV, Hinton R, Ellam RM, Hannigan R, Tan MT, Blusztajn J, Duc NA (2008) Evolving east Asian river systems reconstructed by trace element and $\mathrm{Pb}$ and $\mathrm{Nd}$ isotope variations in modern and ancient Red River-Song Hong sediments. Geochem Geophys Geosyst 9(4):1-29

10. da Silva YJ, A B, do Nascimento CWA, da Silva YJAB, Amorim FF, Cantalice JRB, Singh VP, Collins AL (2018) Bed and suspended sediment-associated rare earth element concentrations and fluxes in a polluted Brazilian river system. Environ Sci Pollut Res 25:34426-34437

11. Delgado J, Perez-Lopez R, Galvan L, Nieto JM, Boski T (2012) Enrichment of rare earth elements as environmental tracers of contamination by acid mine drainage in salt marshes: a new perspective. Mar Pollut Bull 64(9):1799-1808

12. El-Tahera A, Badawy WM, Khater AEM, Madkour HA (2019) Distribution patterns of natural radionuclides and rare earth elements in marine sediments from the Red Sea, Egypt. Appl Radiat Isot 151:171-181 
13. McLennan SM, Nance WB, Taylor SR (1980) Rare earth element-thorium correlations in sedimentary rocks, and the composition of the continental crust. Geochim Cosmochim Ac 44:1833-1839

14. N'Guessan YM, Probst JL, Bur T, Probst A (2009) Trace elements in stream bed sediments from agricultural catchments (Gascogne region, S-W France): where do they come from? Sci Total Environ 407(8):2939-2952

15. Hannigan R, Dorval E, Jones C (2010) The rare earth element chemistry of estuarine surface sediments in the chesapeake bay. Chem Geol 272(1-4):20-30

16. Hatano N, Yoshida K, Mori S, Sasao E (2020) Major element and ree compositions of pliocene sediments in southwest japan: implications for paleoweathering and paleoclimate. Sed Geol 408:105751

17. Hossain HM, Z, Roser BP, Kimura JI (2010) Petrography and whole-rock geochemistry of the Tertiary Sylhet succession, northeastern Bengal Basin, Bangladesh: Provenance and source area weathering. Sed Geol 228:171-183

18. Hu B, Cui R, Li J, Wei H, Zhao J, Bai F, Song W, Ding X (2013) Occurrence and distribution of heavy metals in surface sediments of the Changhua River Estuary and adjacent shelf (Hainan Island). Mar Pollut Bull 76:400-405

19. Khan AM, Yusoff I, Bakar N, Bakar A, Alias Y (2016) Assessing anthropogenic levels, speciation, and potential mobility of rare earth elements (rees) in ex-tin mining area. Environ Sci Pollut Res 23(24):25039-25055

20. Kulaksiz S, Bau M (2007) Contrasting behaviour of anthropogenic gadolinium and natural rare earth elements in estuaries and the gadolinium input into the North Sea. Earth Planet Sci Lett 260:361371

21. Li L, Wu J, Lu J, Min X, Xu J, Yang L (2018) Distribution, pollution, bioaccumulation, and ecological risks of trace elements in soils of the northeastern qinghai-tibet plateau. Ecotoxicol Environ Saf 166:345-353

22. Liu SF, Zhang H, Zhu AM, Wang KS, Chen MT, Khokiattiwong S, Kornkanitnan N, Shi XF (2019) Distribution of rare earth elements in surface sediments of the western gulf of thailand: constraints from sedimentology and mineralogy. Quatern Int 527:52-63

23. Mi BB, Zhang Y, Mei X, Qiu XH, Zhao WN, Lan XH (2020) The rare earth element content in surface sediments of coastal areas in eastern China's sea areas and an analysis of material sources. Geology in China 47(5):1530-1541 :(in Chinese with English abstract .

24. Oral R, Pagano G, Siciliano A, Toscanesi M, Gravina M, Nunzio AD, Palumbo A, Thomas PJ, Tommasi F, Burić P, Lyons DM, Guida M, Trifuoggi M (2019) Soil pollution and toxicity in an area affected by emissions from a bauxite processing plant and a power plant in gardanne (southern france). Ecotoxicol Environ Saf 170:55-61

25. Qiao JY, Tang J, Xue Q (2020) Study on pb release by several new lixiviants in weathered crust elution-deposited rare earth ore leaching process: behavior and mechanism. Ecotoxicol Environ Saf 190:110138 
26. Renjan S, Rao VP, Kessarkar PM (2017) Major and trace metals in suspended and bottom sediments of the mandovi and zuari estuaries, western india: distribution, source, and pollution. Environmental Science Pollution Research 24:27409-27429

27. Sholkovitz ER, Szymczak R (2000) The estuarine chemistry of rare earth elements:comparison of the Amazon, Fly, Sepik and the Gulf of Papua systems. Earth Planet Sci Lett 179:299-309

28. Sutherland RA (2000) Bed sediment-associated trace elements in an urban stream. Oahu Hawai Environmental Geology 39:330-341

29. Trifuoggi M, Donadio C, Ferrara L, Stanislao C, Toscanesi M (2018) Levels of pollution of rare earth elements in the surface sediments from the gulf of pozzuoli (campania, italy). Mar Pollut Bull 136:374-384

30. Wang Y, Shen JW, Wang X, Yang HQ, Liu MM (2011) Ree distribution pattern in the Xiaobonghai fringing Reef-flat sediments off Sanya, Hainan island and its environmental implications. Marine geology quaternary geology 31(5):59-66 (in Chinese with English abstract)

31. Wang S, Zhang N, Chen H, Li L, Yan W (2014) The surface sediment types and their rare earth element characteristics from the continental shelf of the northern south China sea. Continent Shelf Res 88:185-202

32. Wang H, Wang J, Liu R, Yu W, Shen Z (2015) Spatial variation, environmental risk and biological hazard assessment of heavy metals in surface sediments of the Yangtze River estuary. Mar Pollut Bull 93:250-258

33. Wang LQ, Han XX, Ding SM, Liang T, Zhang YY, Xiao J, Dong LL, Zhang HD (2019) Combining multiple methods for provenance discrimination based on rare earth element geochemistry in lake sediment. Science of The Total Environment 672:264-274

34. Wilding L (1985) Spatial variability: its documentation, accomodation and implication to soil surveys. Soil spatial variability, Las Vegas NV, 30 November-1 December 1984, pp 166-194

35. Wu K, Liu S, Shi X, Lou Z, Che A (2020) Distribution of rare earth elements in surface sediments of the western sunda shelf: constraints from sedimentology and mineralogy. Cont Shelf Res 206:104198

36. Xu Z, Han G (2009) Rare earth elements (REE) of dissolved and suspended loads in the Xijiang River, South China. Appl Geochem 24:1803-1816

37. Xu F, Tian X, Yin X, Yan H, Yin F, Liu Z (2015) Trace metals in the surface sediments of the eastern continental shelf of hainan island: sources and contamination. Mar Pollut Bull 99(1-2):276-283

38. Zhao L, Liu JQ, Cai GQ, Huang L, Luo WD (2020) Distribution, source, and pollution assessment of heavy metals in Sanya offshore area, south Hainan Island of China. Mar Pollut Bull 160:111561

39. Zhang Y, Gao X (2015) Rare earth elements in surface sediments of a marine coast under heavy anthropogenic influence: the bohai bay, china. Estuarine Coastal Shelf Science 164:86-93

\section{Figures}




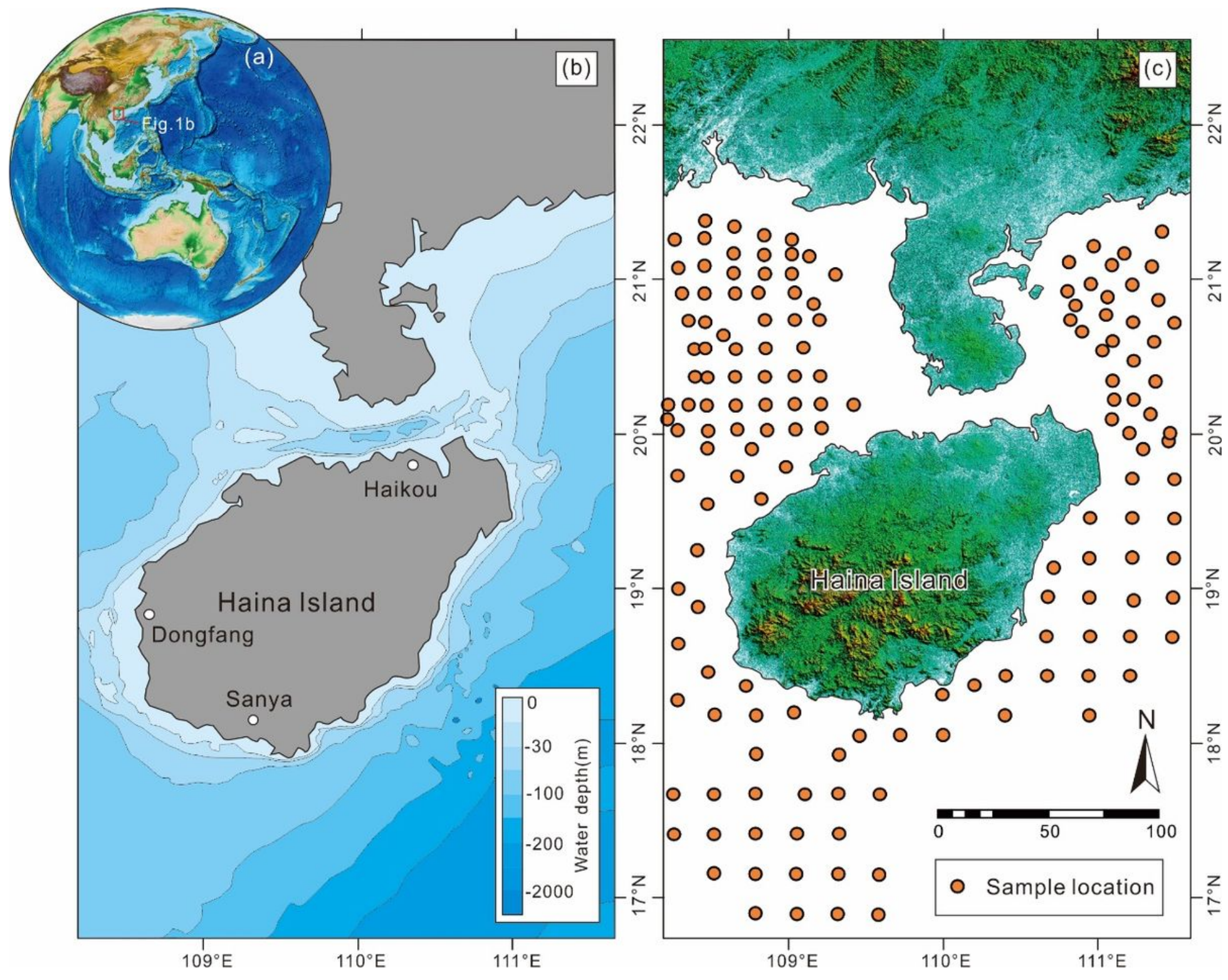

Figure 1

Location of the study area and sampling sites Note: The designations employed and the presentation of the material on this map do not imply the expression of any opinion whatsoever on the part of Research Square concerning the legal status of any country, territory, city or area or of its authorities, or concerning the delimitation of its frontiers or boundaries. This map has been provided by the authors. 


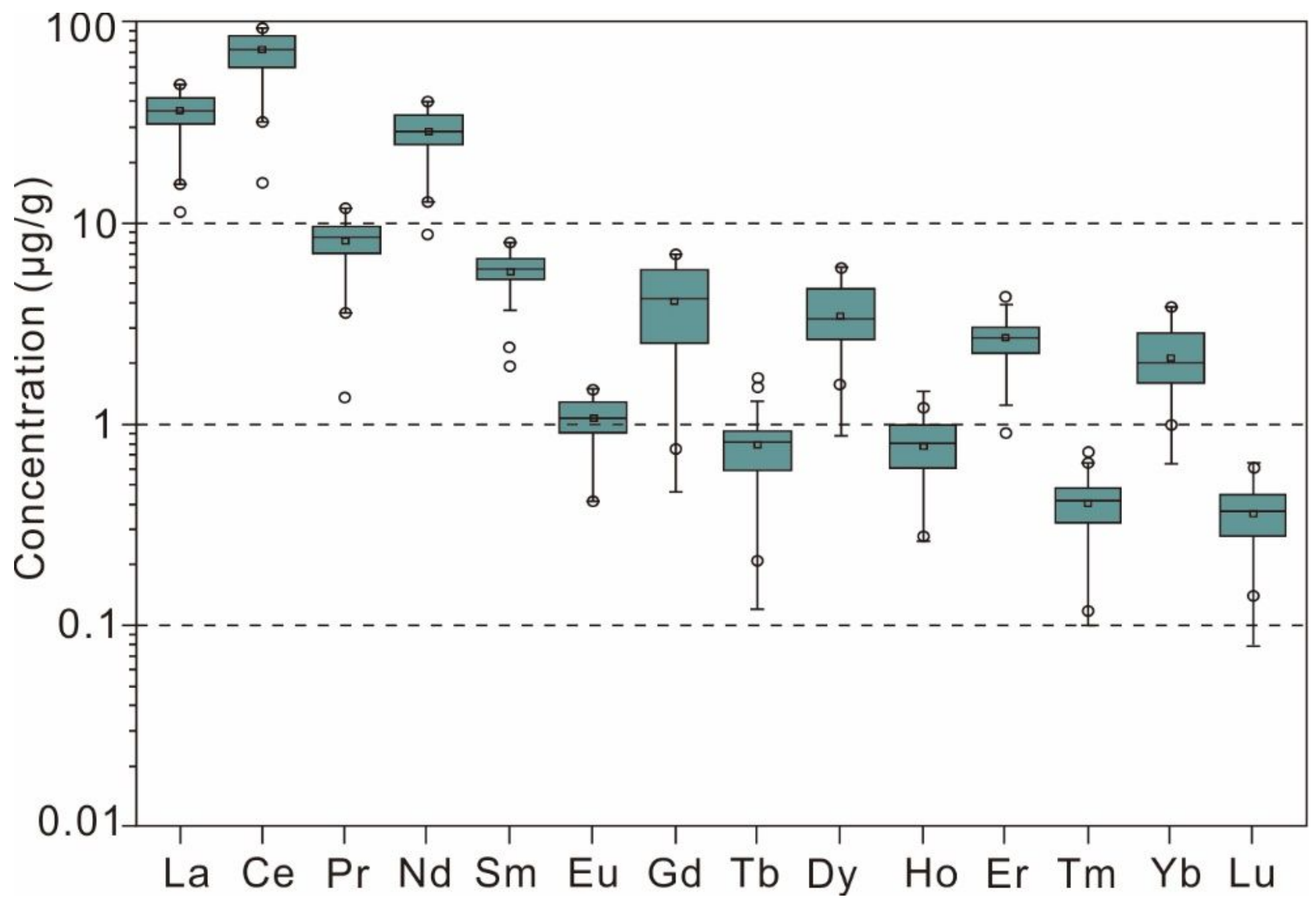

Figure 2

The concentration and mean of REEs in surface sediments of the CSHI. 

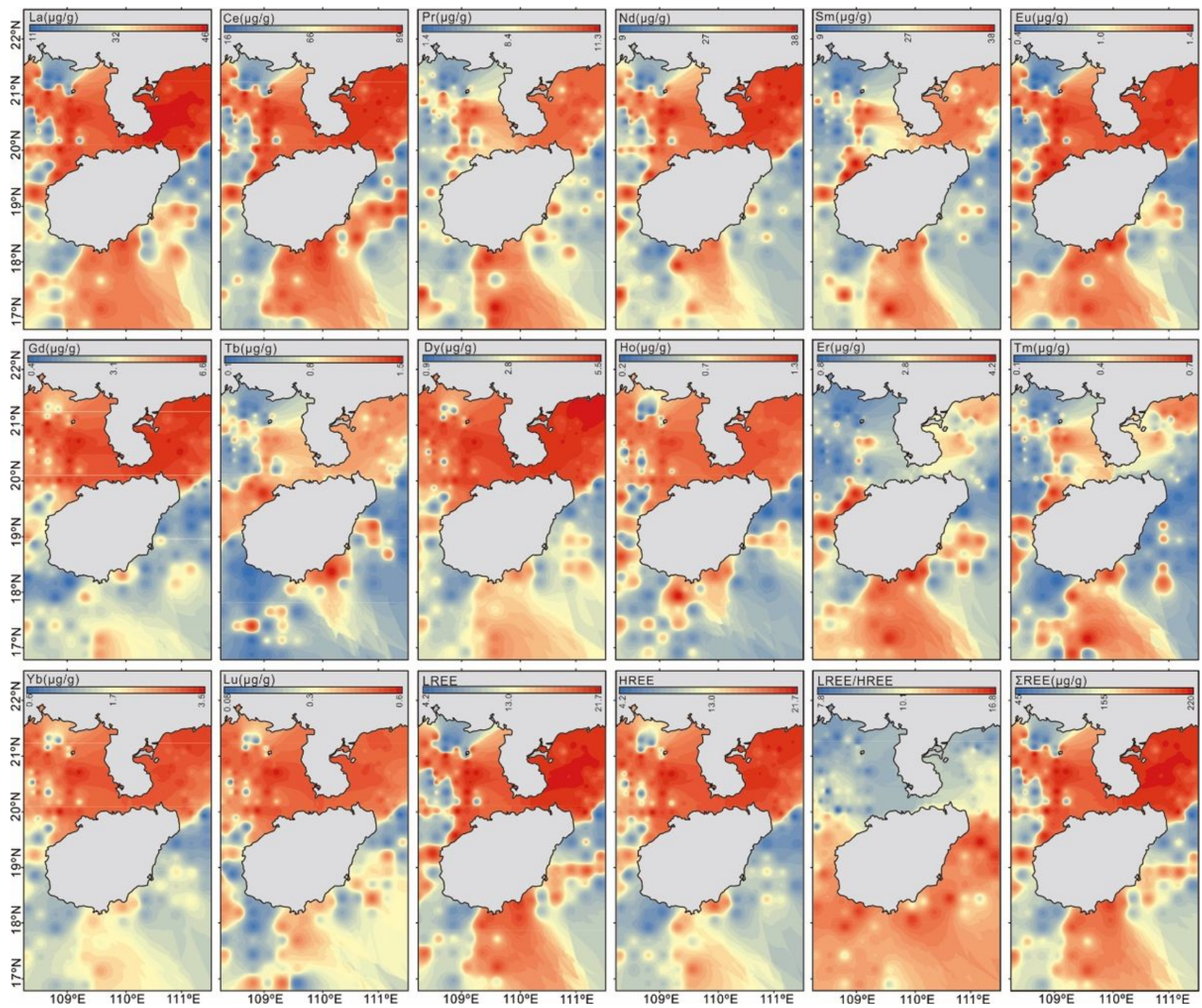

Figure 3

Spatial distribution of REEs in surface sediments of the CSHI. Note: The designations employed and the presentation of the material on this map do not imply the expression of any opinion whatsoever on the part of Research Square concerning the legal status of any country, territory, city or area or of its authorities, or concerning the delimitation of its frontiers or boundaries. This map has been provided by the authors. 


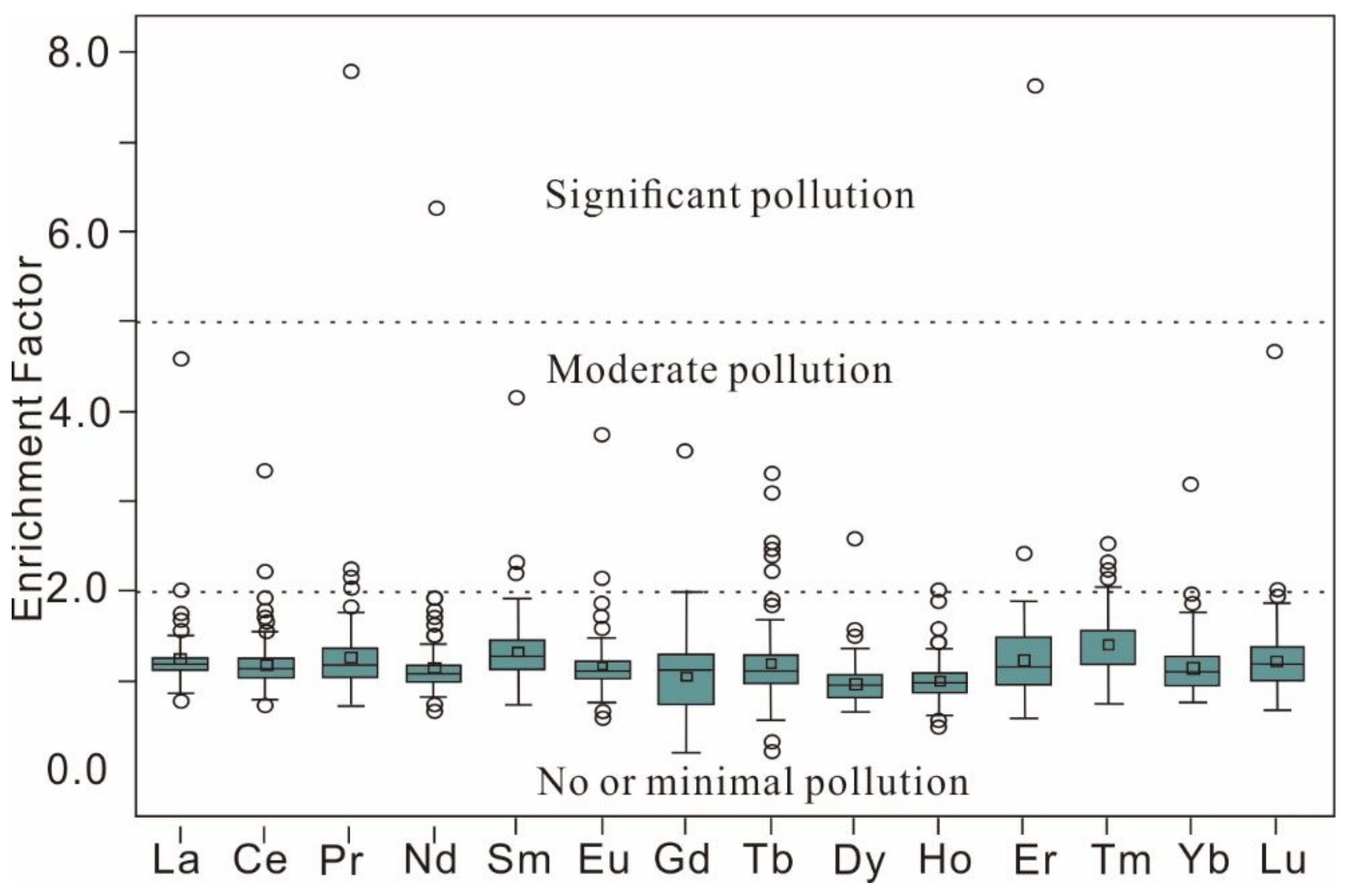

Figure 4

Enrichment factor of REEs in surface sediments of the CSHI. 

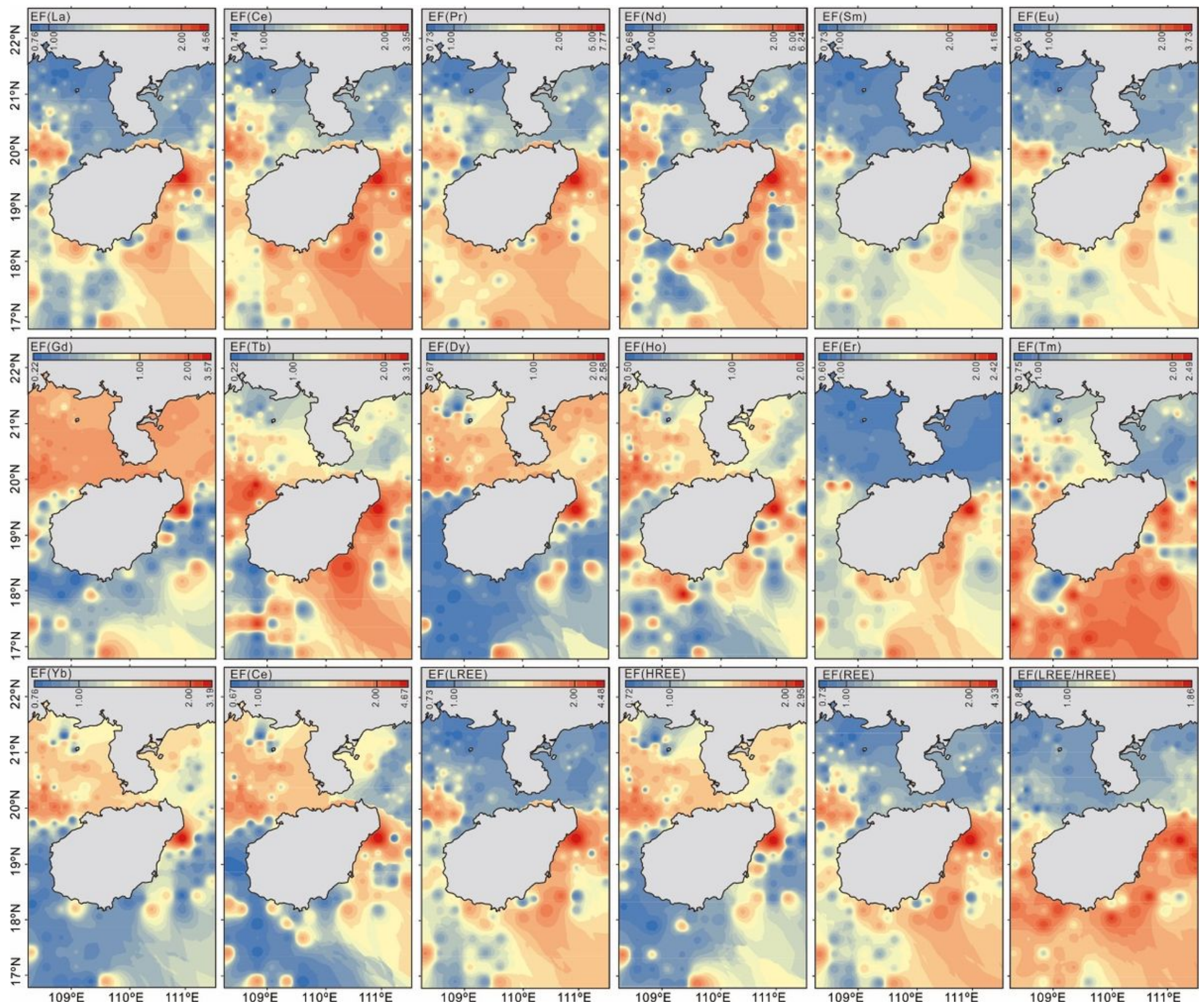

Figure 5

Spatial distributions of the EF values for REEs in surface sediments of the CSHI. Note: The designations employed and the presentation of the material on this map do not imply the expression of any opinion whatsoever on the part of Research Square concerning the legal status of any country, territory, city or area or of its authorities, or concerning the delimitation of its frontiers or boundaries. This map has been provided by the authors. 


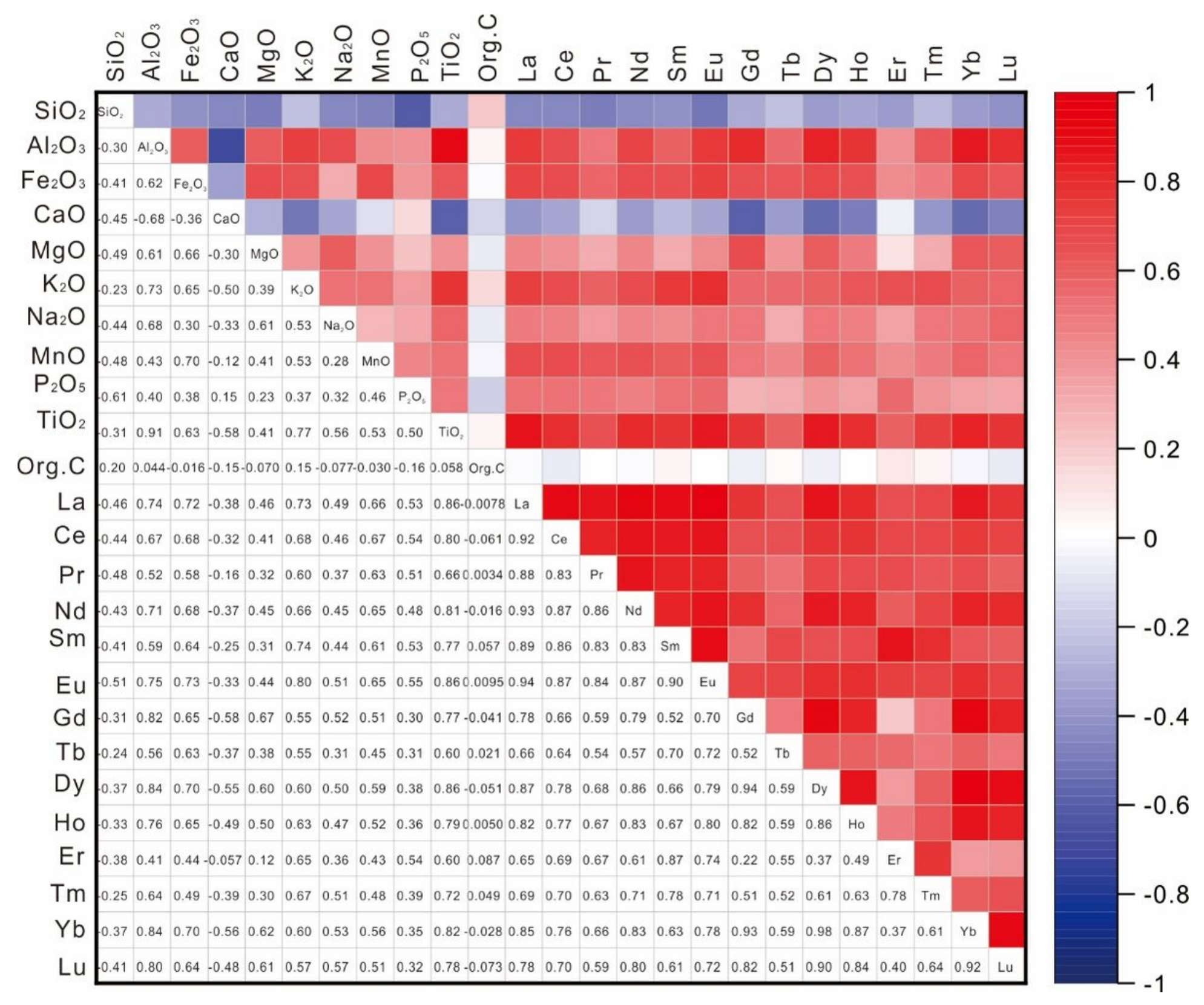

Figure 6

Pearson's correlation coefficients among element concentrations in the sediments of the CSHI. 

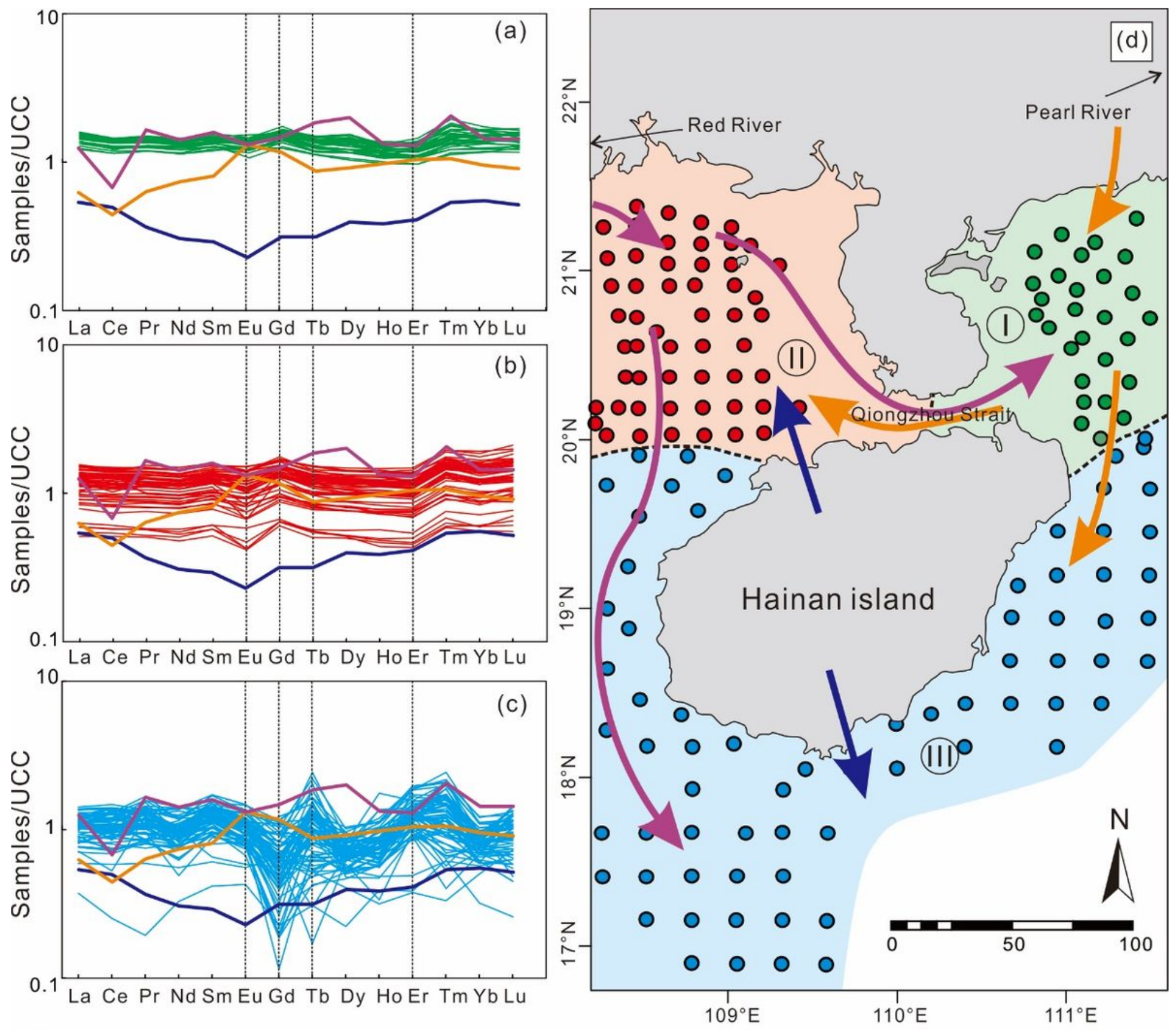

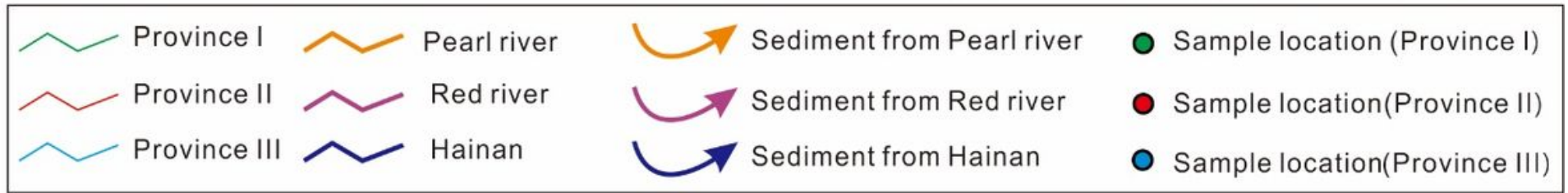

Figure 7

UCC-normalized REE patterns of sediments in different provinces. a-province l; b-province II; c-province III. d. Sediment sources and transport patterns in the CSHI. Data sources: Pearl river (Xu and Han,2009), Red river (Clift et al., 2008), Soil of Hainan island (Wang et al.,2011) Note: The designations employed and the presentation of the material on this map do not imply the expression of any opinion whatsoever on the part of Research Square concerning the legal status of any country, territory, city or area or of its 
authorities, or concerning the delimitation of its frontiers or boundaries. This map has been provided by the authors.

\section{Supplementary Files}

This is a list of supplementary files associated with this preprint. Click to download.

- ecomponent.doc 